\title{
SYNTHESIS OF SOME NOVEL 2-AMINOTHIOPHENE DERIVATIVES AND EVALUATION FOR THEIR ANTIMICROBIAL ACTIVITY
}

\author{
Kalakota Chaitanya prasad ${ }^{1 *}$, Bheema Naik Angothu ${ }^{2}$, Thota Madhu Latha ${ }^{3}$, Malothu Nagulu ${ }^{4}$ \\ ${ }^{1}$ Assistant Professor, Department of Pharmaceutical Chemistry, Swami Ramananda Tirtha Institute of \\ Pharmaceutical Sciences, Ramananda Nagar, Post S.L.B.C, Nalgonda -508004 Telangana, India. \\ ${ }^{2}$ Assistant Professor, Department of Pharmaceutical Chemistry, Swami Ramananda Tirtha Institute of \\ Pharmaceutical Sciences, Ramananda Nagar, Post S.L.B.C, Nalgonda -508004 Telangana, India. \\ ${ }^{3}$ Post Graduate, Department of Pharmaceutical Chemistry, ANU College of Pharmaceutical Sciences,
}

Guntur-522003, Andra Pradesh, India.

${ }^{4}$ Professor, Department of Pharmacology, Swami Ramananda Tirtha Institute of Pharmaceutical Sciences, Ramananda Nagar, Nalgonda -508004 Telangana, India.

\begin{abstract}
*Corresponding Author Email: c496004@gmail.com
ABSTRACT

Chemistry of 2-aminothiophenes is arguably one of the most extensive and dynamic field of present-day research. Highly substituted thiophene derivatives are important heterocyclic compounds found in numerous biologically active and natural compounds.2-aminothiophenes forms a significant class of drugs which exhibits the excellent biological activities like antimicrobial, antifungal, anti-inflammatory, analgesic, antioxidant, antitumor activities. In continuation of our previous studies on synthesis of substituted 2-aminothiophenes and due to their significant biological properties, we now report the newly synthesized ethyl 2-amino-4-phenylthiophene-3-carboxylate derivatives are obtained by base protanated reaction between ketone, elemental sulphur with ethylcayanoacetate in the presence of diethyl amine. The newely synthesized targeted compounds were characterized by spectral analysis studies and screened for their antibacterial activity by using minimum inhibitory concentration (MIC) method by taking ampicilline and streptomycine as standard.
\end{abstract}

\section{KEY WORDS}

Substituted 2-aminothiophenes, Gewald synthesis, Antimicrobial activity, MIC method.

\section{INTRODUCTION}

A large number of medicinal compounds which have been discovered belong to a major class of heterocycles containing Nitrogen and Sulphur. The versatile synthetic applicability and biological activity of these heterocycles has helped the medicinal chemist to plan, organize and implement new approaches towards the discovery of novel drugs. Thiophenes and its derivatives are an important class of heterocyclic compound, specifically, 2-amino substituted thiophenes reported to possess a wide spectrum of biological properties such as antibacterial, antifungal, analgesic, anti-inflammatory, antioxidant and antitumor and local anaesthetic activity. For example, thiophene containing $\beta$-lactam antibiotics like Ticarcillin, Cefoxitin, Cephalothin and Cephalorodine have shown good antibacterial activity [1]. The significance of 2-aminothiophenes leads us to the present study where the data on synthesis and biological activities of various substituted 2aminothiophenes are systemized and analysed by spectral analysis [2]. We have attempted the synthesis of some new compounds which contains thiophene nucleus in its structure [3]. We have synthesized ethyl 2-amino-4-phenylthiophene-3-carboxylate as the starting compound derivatized the starting compound to various substituted ethyl 2-amino-4phenylthiophene-3-carboxylates $(2 \mathrm{a}-2 \mathrm{f})$. 


\section{MATERIALS AND METHODS}

\section{Chemistry}

Reagents and Solvents were procured from commercial sources and were dried and purified according to literature survay. The melting points were determined with an electro thermal melting point apparatus. Infrared spectra ( $\mathrm{KBr}$ disc) were perfumed on FTIR-8400 Shimadzu and the frequencies were expressed in $\mathrm{cm}-1$. $1 \mathrm{H}$ NMR spectra were recorded on Bruker-Avance 400 $\mathrm{MHz}$ instrument with TMS (0 ppm) as an internal standard; the chemical shifts $(\delta)$ are reported in ppm and coupling constants $(\mathrm{J})$ are given in Hertz $(\mathrm{Hz})$. Signal multiplicities are represented by $\mathrm{s}$ (singlet), $\mathrm{d}$ (doublet), $\mathrm{t}$ (triplet), dd (double doublet), m(multiplet) and br $s$ broad singlet). The reactions were followed and the purity of the compounds was checked by TLC on silica gel-precoated aluminium sheets.

General procedure for the synthesis of starting material ethyl 2-amino-4-phenylthiophene-3carboxylate (1)

To a mixture of ethylcyanoacetate $(0.1 \mathrm{~mol})$ and ketone (0. $1 \mathrm{~mol}$ ) were dissolved in $150 \mathrm{ml}$ of absolute ethanol. Elemental sulphur powder $(0.1 \mathrm{~mol})$ and appropriate base $(20 \mathrm{ml})$ were added. The mixture was heated at 55 to $65{ }^{\circ} \mathrm{C}$ during 2 hours and then was cooled in refrigerator for overnight. During the cooling the formed precipitate was separated out. The precipitate was collected and recrystalized with suitable solvent [47].

General procedure for the synthesis of starting material ethyl 2-amino-4-phenylthiophene-3carboxylate derivatives

Dissolve $0.05 \mathrm{M}$ of 2-aminothiophene (1) and $0.05 \mathrm{M}$ of aldehydes (a-f), $25 \mathrm{ml}$ of dry Dimethylformamide and $\mathrm{HCl}$ $0.2 \mathrm{ml}$ was taken in a round bottomed flask for condensation and allow the reaction mixture to reflux for $3 \mathrm{hrs}$. Then the reaction mixture was stand overnight in the refrigerator and was poured into crushed ice.The precipitate thus obtained was filtered off and washed with water and recrystallized with suitable solvent $[8,9]$. Ethyl 2-(2-chlorophenylamino)-4-phenylthiophene-3carboxylate(2a)

Yield 71\%, M.P $203^{\circ}$ C,IR(KBr) :3312(N-H str), 1523 (C$\mathrm{N}), 1714(\mathrm{C}=\mathrm{O}), 1446(\mathrm{C}=\mathrm{C}), 2951(\mathrm{C}-\mathrm{H}), 1 \mathrm{H} \mathrm{NMR}(\mathrm{CDCl} 3) \delta$ :

\section{$1.30\{\mathrm{t}, 3 \mathrm{H}, \mathrm{H}$-ester $\}, 4.29\left\{\mathrm{q}, 2 \mathrm{H},-\mathrm{OCH}_{2}\right\}, 6.3\{\mathrm{~S}, 1 \mathrm{H}, \mathrm{H}-$} thiophene $, 6.40-7.48\{\mathrm{~m}, 9 \mathrm{H}, \mathrm{H}-\mathrm{Ar}$ and $\mathrm{Ph}\}, 4.0\{\mathrm{~S}, 1 \mathrm{H}, \mathrm{C}-$ $\mathrm{NH}$. Anal. calcd: $\mathrm{C}, 63.77 ; \mathrm{H}, 4.51 ; \mathrm{Cl}, 9.91 ; \mathrm{N}, 3.91$; 0,8.94; S,8.96

Ethyl 2-(3-nitrophenylamino)-4-phenylthiophene-3carboxylate(2b)

Yield 73\%, M.P $227^{\circ}$ C, IR(KBr) : 3256(N-H str), 1462 (C$\mathrm{N}), 1692(\mathrm{C}=\mathrm{O}), 1456(\mathrm{C}=\mathrm{C}), 2392(\mathrm{C}-\mathrm{H}), 1 \mathrm{H} \mathrm{NMR}(\mathrm{CDCl} 3) \delta$ : $1.29\{\mathrm{t}, 3 \mathrm{H}, \mathrm{H}$-ester $\}, 4.29\left\{q, 2 \mathrm{H},-\mathrm{OCH}_{2}\right\}, 6.3\{\mathrm{~S}, 1 \mathrm{H}, \mathrm{H}-$ thiophene $\}, 6.40-7.48\{\mathrm{~m}, 9 \mathrm{H}, \mathrm{H}-\mathrm{Ar}$ and $\mathrm{Ph}\}, 4.1\{\mathrm{~S}, 1 \mathrm{H}, \mathrm{C}-$ NH\}. Anal. Calcd: C, 61.94; H, 4.38; N, 7.60; O, 17.37; S, 8.70 .

Ethyl 2-(4-hydroxyphenylamino)-4-phenylthiophene3-carboxylate(2c)

Yield 74\%, M.P $216^{\circ}$ C, IR (KBr) :3326(N-H str), 1352(C$\mathrm{N}), \quad 1646(\mathrm{C}=\mathrm{O}), \quad 1561(\mathrm{C}=\mathrm{C}), 3056(\mathrm{C}-\mathrm{H}), 3363(-\mathrm{OH}), 1 \mathrm{H}$ NMR $(\mathrm{CDCl} 3) \quad \delta: \quad 1.30 \quad\{\mathrm{t}, 3 \mathrm{H}, \mathrm{H}$-ester $\}, 5.0\{\mathrm{~S}, 1 \mathrm{H}, \mathrm{C}-$ $\mathrm{OH}\}, 4.29\left\{\mathrm{q}, 2 \mathrm{H},-\mathrm{OCH}_{2}\right\}, 6.29\{\mathrm{~S}, 1 \mathrm{H}, \mathrm{H}$-thiophene $\}, 6.40-$

$7.48\{\mathrm{~m}, 9 \mathrm{H}, \mathrm{H}-\mathrm{Ar}$ and $\mathrm{Ph}\}, 4.2\{\mathrm{~S}, 1 \mathrm{H}, \mathrm{C}-\mathrm{NH}\}$. Anal.calcd: C, $67.24 ; \mathrm{H}, 5.05 ; \mathrm{N}, 4.13 ; \mathrm{O}, 14.14 ; \mathrm{S}, 9.45$.

2-(Furan-2-ylamino)-4-phenyl-thiphene-3carboxylicacid ethyl ester(2d)

Yield 71\%, M.P $232^{\circ} \mathrm{C}, \mathrm{IR}(\mathrm{KBr}): 3398(\mathrm{~N}-\mathrm{H}$ str), 1275(C$\mathrm{N}), 1682(\mathrm{C}=\mathrm{O}), 1448(\mathrm{C}=\mathrm{C}), 2859(\mathrm{C}-\mathrm{H}), 1 \mathrm{H} \mathrm{NMR}(\mathrm{CDCl} 3)$ $\delta: \quad 1.30\{\mathrm{t}, 3 \mathrm{H}, \mathrm{H}$-ester $\}, 6.30-7.48\{\mathrm{~m}, 8 \mathrm{H}, \mathrm{H}-\mathrm{Ar}$ and $\mathrm{Ph}\}, 5.0\{\mathrm{~S}, 1 \mathrm{H}, \mathrm{C}-\mathrm{OH}\}, 4.30\left\{\mathrm{q}, 2 \mathrm{H},-\mathrm{OCH}_{2}\right\}, 6.30\{\mathrm{~S}, 1 \mathrm{H}, \mathrm{H}-$ thiophene\}, 4.0\{S,1H,C-NH\}.Anal. calcd C, 65.16; $\mathrm{H}$, $4.82 ; \mathrm{N}, 4.47 ; \mathrm{O}, 15.32 ; \mathrm{S}, 10.23$.

2-(4-Methoxy-phenylamino)-4-phenyl-thiophene-3carboxylicacid ethyl ester (2e)

Yield 70.5\%, M.P $253^{\circ} \mathrm{C}$, IR(KBr) :3258(N-H str), 1316(CN), $\quad 1756(\mathrm{C}=\mathrm{O}), \quad 1398(\mathrm{C}=\mathrm{C}), \quad 2836(\mathrm{C}-\mathrm{H}), \quad 1 \mathrm{H}$ $\operatorname{NMR}(\mathrm{CDCl} 3) \delta: 1.30\{\mathrm{t}, 3 \mathrm{H}, \mathrm{H}$-ester $\}, 4.29\{\mathrm{q}, 2 \mathrm{H},-$

$\left.\mathrm{OCH}_{2}\right\}, 6.30-7.48\{\mathrm{~m}, 9 \mathrm{H}, \mathrm{H}-\mathrm{Ar}$ and $\mathrm{Ph}\}, 3.73\{\mathrm{t}, 3 \mathrm{H},-$ $\left.\mathrm{OCH}_{2}\right\}, 4.0\{\mathrm{~S}, 1 \mathrm{H}, \mathrm{C}-\mathrm{NH}\}, 6.30\{\mathrm{~S}, 1 \mathrm{H}, \mathrm{H}-$

thiophene\}.Anal.calcd: C, 67.97; H, 5.42; N, 3.96; O, 13.58; S, 9.07.

4-phenl-2-(thiophe-2-ylamino)-thiophene-3carboxylicacid ethyl ester $\left(2_{\mathrm{f}}\right)$

Yield 72\%, M.P $256^{\circ}$ C, IR(KBr) : 3359(N-H str),1217(C$\mathrm{N}), 1712(\mathrm{C}=\mathrm{O}), 1515(\mathrm{C}=\mathrm{C}), 2859(\mathrm{C}-\mathrm{H}), 1 \mathrm{H} \mathrm{NMR}(\mathrm{CDCl} 3)$ $\delta: \quad 1.30\{\mathrm{t}, 3 \mathrm{H}, \mathrm{H}$-ester $\}, 4.29\left\{\mathrm{q}, 2 \mathrm{H},-\mathrm{OCH}_{2}\right\}, 6.3\{\mathrm{~S}, 1 \mathrm{H}, \mathrm{H}-$ thiophene $\}, 6.30-7.48\{\mathrm{~m}, 8 \mathrm{H}, \mathrm{H}-\mathrm{Ar}$ and $\mathrm{Ph}\}, 4.0\{\mathrm{~S}, 1 \mathrm{H}, \mathrm{C}-$ $\mathrm{NH}$. Anal calcd: C, 61.98; H, 4.59; N, 4.25; O, 9.71; S, 19.47 . 


\section{SCHEME}<smiles>[R]CC([R])=O</smiles>

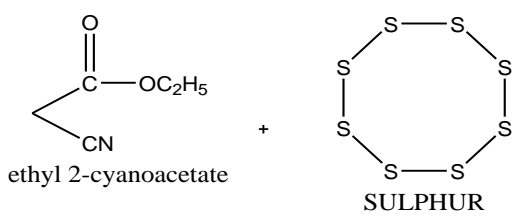

Base, $45^{0}-55^{\circ} \mathrm{c}$

Stirring

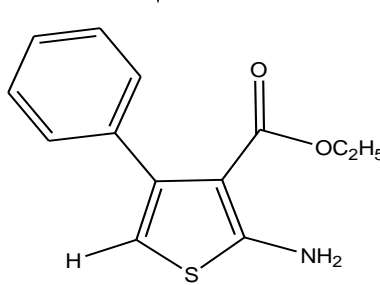

1-(2-amino-4-phenylthiophen-3-yl)propan-1-one

$\mathrm{ArCHO}$

\section{BIOLOGICAL SCREENING}

Antibacterial tests were performed at the Department of Microbiology, Swamiramanandatirtha Institute of pharmaceutical sciences, Nalgonda.

\section{ANTIBACTERIAL SCREENING}

The antibacterial studies of 2-aminothiophene derivatives were carried out against a battery of microorganisms. The antibacterial activity of the test compounds was assayed systematically against ' 4 ' different strains of bacteria i.e E.coli, P.vulgaris, and B.subtilis by S.aureus serial dilution method. Generally, the antibacterial activity of a compound is expressed in terms of its ability to inhibit the growth of bacteria in nutrient broth by Minimum inhibitory concentration method.

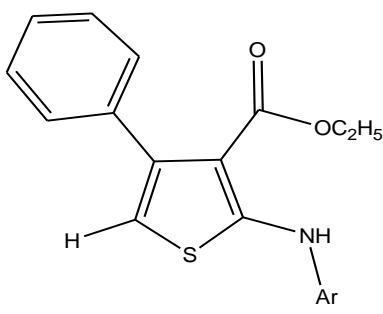

$\left[2{ }_{\mathrm{a}}-2_{\mathrm{f}}\right]$

\section{MINIMUM INHIBITORY CONCENTRATION}

The newly synthesized compounds were screened for anti-bacterial activity studies at a concentration of $20 \mu \mathrm{g} / \mathrm{ml}$ using Di methyl formamide as a control against gram $^{+}$ve Bacillus Substilis and gram ve E.Coli bacteria. The antibacterial activity of the test compounds were compared with Ampicillin and Streptomycin.

Serial dilutions of the test compounds and standard drugs were prepared in DMF.

Minimum inhibitory concentration is the lowest concentration of an compound that will inhibit the visible growth of a microorganism after $24 \mathrm{hr}$ incubation.

Minimum inhibitory concentration is important in diagnostic laboratories to confirm resistance to 
microorganism to an antimicrobial agent and also to monitor the activity of new antimicrobial agents.

A Minimum inhibitory concentration is generally regarded as the most basic laboratory measurement of the activity of an antimicrobial agent against a organism.

\section{DETERMINATION}

- Preparation of antibiotic stock solution

- Preparation of antibiotic dilution range

- Preparation agar dilution plates

- Preparation of inoculum

- Inoculation

- Incubation

- Reading and interpreting results

PREPARATION OF NUTRIENT BROTH MEDIUM:

$13.6 \mathrm{grs}$ of nutrient broth dissolved in $1000 \mathrm{ml}$ of distilled water. The prepared media was sterilized under autoclave at $120 \mathrm{lb} / 1$ hour.

\section{PREPARATION OF TEST SOLUTIONS:}

$10 \mathrm{mg}$ of test sample was dissolved in $10 \mathrm{ml}$ of Dimethylformamide.

PREPARATION OF STANDARD SOLUTIONS:

$10 \mathrm{mg}$ of standard drug was dissolved in $10 \mathrm{ml}$ of DMF. PREPARATION OF STOCK SOLUTION:

From test and standard solutions $2 \mathrm{ml}$ of solutions were taken in different volumetric flasks and these are made up with DMF up to $20 \mathrm{ml}$.this equivalent to $200 \mu \mathrm{g} / \mathrm{ml}$.

\section{PREPARATION OF SERIAL DILUTIONS:}

\section{DILUTION 1:}

$4 \mathrm{ml}$ of stock solution taken in a test tube and add $2 \mathrm{ml}$ of nutrient broth medium. This equivalent to $200 \mu \mathrm{g} / \mathrm{ml}$. DILUTION 2:

From dilution 1 we have taken the $2 \mathrm{ml}$ sample and add $2 \mathrm{ml}$ of nutrient broth medium. This equivalent to $100 \mu \mathrm{g} / \mathrm{ml}$.

\section{DILUTION 3:}

From dilution 2 we have taken the $2 \mathrm{ml}$ sample and add $2 \mathrm{ml}$ of nutrient broth medium. This equivalent to $50 \mu \mathrm{g} / \mathrm{ml}$.

\section{DILUTION 4:}

From dilution 3 we have taken the $2 \mathrm{ml}$ of sample and add $2 \mathrm{ml}$ of nutrient broth medium. This equivalent to $25 \mu \mathrm{g} / \mathrm{ml}$.

\section{DILUTION 5:}

From dilution 4 we have taken the $2 \mathrm{ml}$ of sample and add $2 \mathrm{ml}$ of nutrient broth medium. This equivalent to $12.5 \mu \mathrm{g} / \mathrm{ml}$. In this $2 \mathrm{ml}$ was discarded.

These 5 dilutions were prepared individually for 3 micro-organisms. The organisms were inoculated in test tubes under laminar air flow in aseptic conditions. The test tubes were incubated at $37^{\circ} \mathrm{c}$ for $24 \mathrm{hrs}$.

The MIC was the lowest concentration of the tested compound that yields no visible growth on the test tube.

\section{RESULTS \& DISCUSSION}

All the compounds have been evaluated for their antibacterial activity against Bacillus substilis, Escherichia coli, Proteus vulgarise (G-ve) and S.aureus. The results of the evaluation have been viewed by taking Ampicillin and Streptomycin a broad spectrum antibiotic as the standard. Table 2 and 3 pertaining to the antibacterial data of 2-aminothiophene derivatives shows all the compounds of the series have been relatively more active against $B$.subtilis among all the compounds, compound $\mathbf{2}$ c has been found to be greater inhibitory effect against the organisms employed, particularly against B.subtilis, E.coli, P.vulgaris and S.aureus with MIC. 
Derivatives of 2-aminothiophenes

Table 1. Physico chemical properties

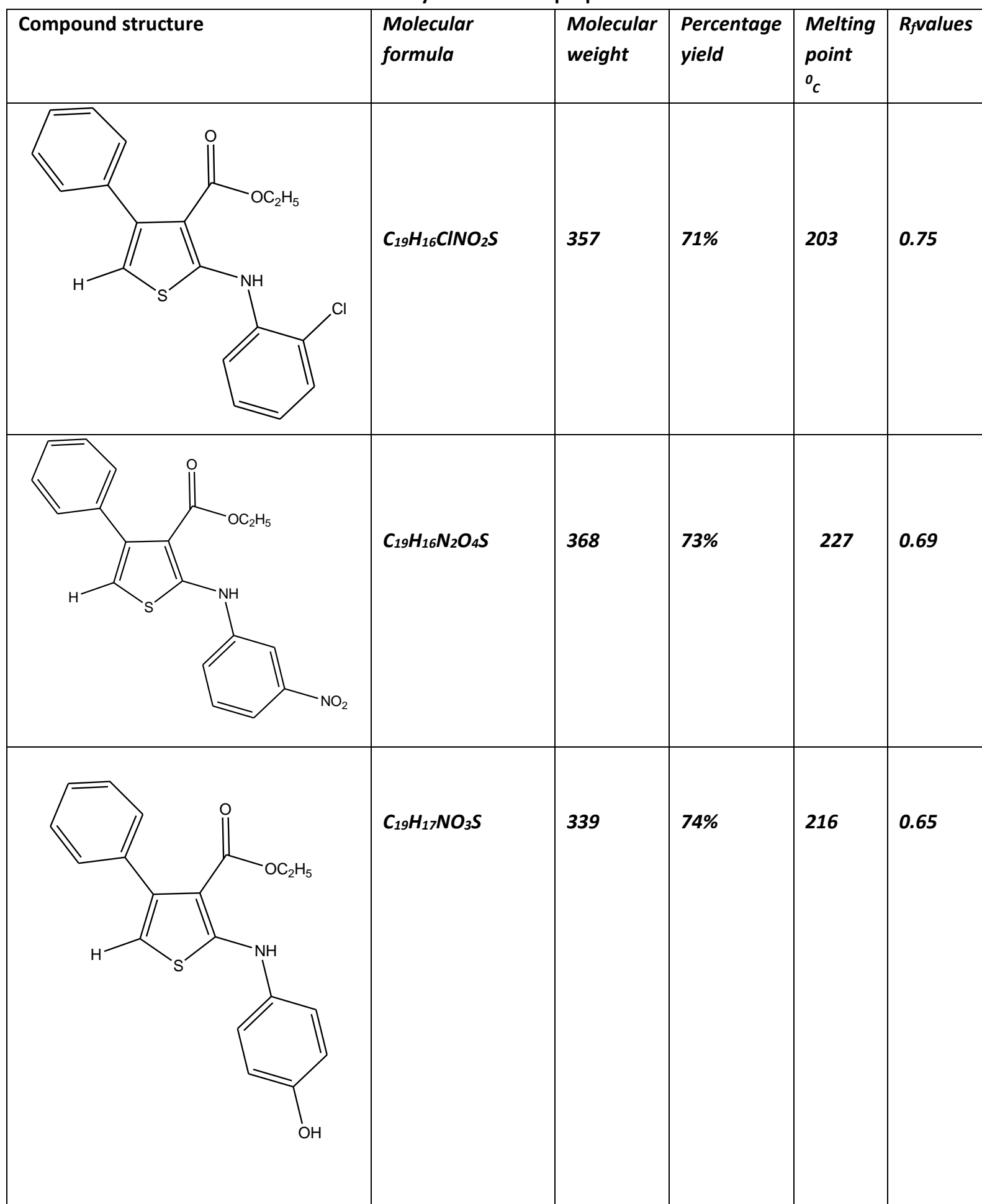




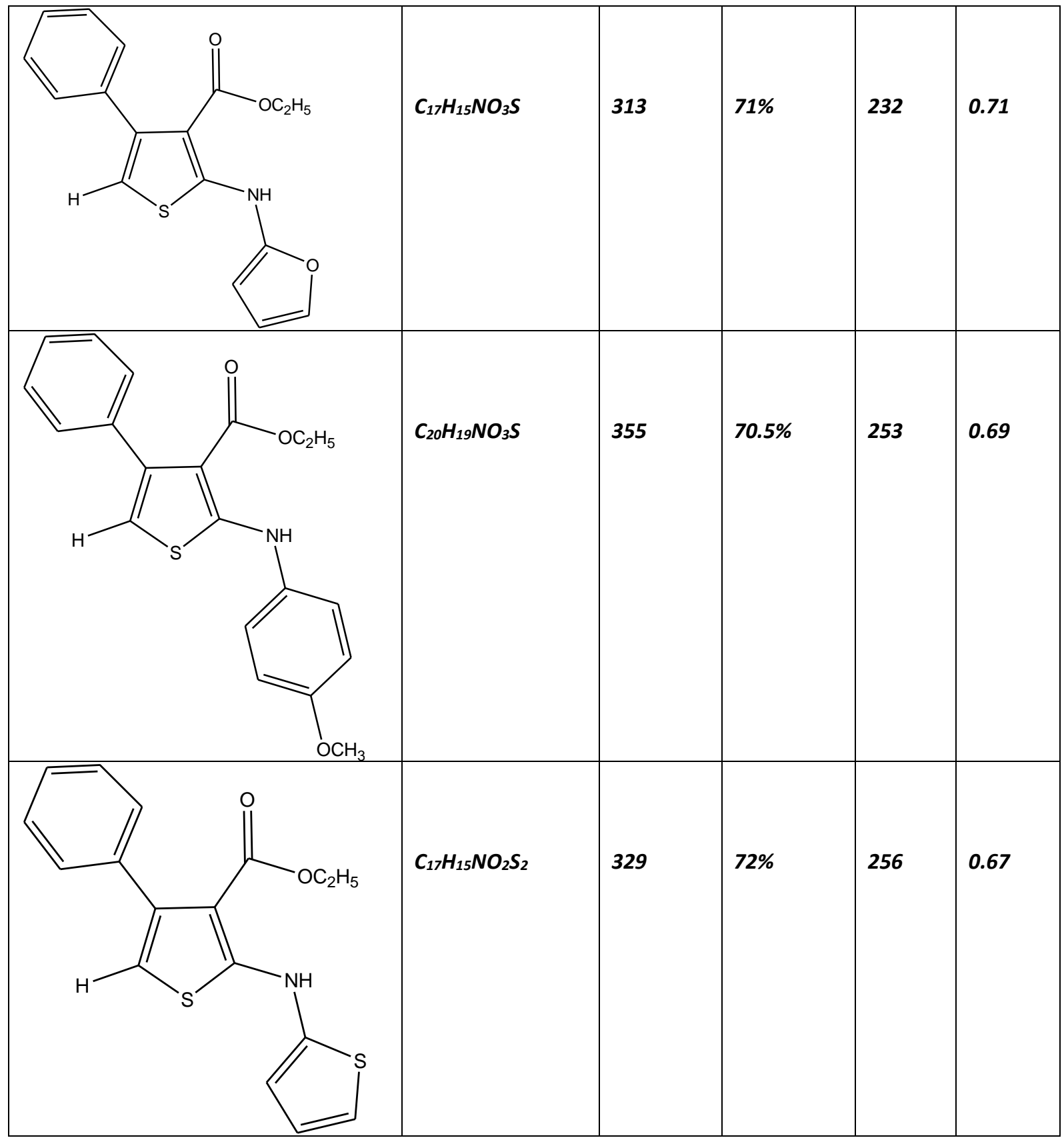

Table 2. Antimicrobial activity of standard drugs

\begin{tabular}{llllll}
\hline S.NO & Standard drug & Proteusvulgaris & Bacillussubstilis & E.coli & S.aureus \\
\hline 1 & Ampicillin & $25 \mu \mathrm{g}$ & $50 \mu \mathrm{g}$ & $12.5 \mu \mathrm{g}$ & $50 \mu \mathrm{g}$ \\
2 & Streptomycin & $12.5 \mu \mathrm{g}$ & $50 \mu \mathrm{g}$ & $12.5 \mu \mathrm{g}$ & $25 \mu \mathrm{g}$ \\
\hline
\end{tabular}


Table 3. Antimicrobial activity of 2-aminothiophene derivatives

\begin{tabular}{llllll}
\hline S.NO & Sample Name & Proteusvulgaris & Bacillussubtilis & E.Coli & S.aureus \\
\hline 1 & $2 \mathrm{a}$ & $12.5 \mu \mathrm{g}$ & $12.5 \mu \mathrm{g}$ & $12.5 \mu \mathrm{g}$ & $25 \mu \mathrm{g}$ \\
2 & $2_{\mathrm{b}}$ & $100 \mu \mathrm{g}$ & $50 \mu \mathrm{g}$ & $12.5 \mu \mathrm{g}$ & $25 \mu \mathrm{g}$ \\
3 & $2_{\mathrm{c}}$ & $25 \mu \mathrm{g}$ & $50 \mu \mathrm{g}$ & $12.5 \mu \mathrm{g}$ & $50 \mu \mathrm{g}$ \\
4 & $2_{\mathrm{d}}$ & $25 \mu \mathrm{g}$ & $50 \mu$ & $25 \mu \mathrm{g}$ & $12.5 \mu \mathrm{g}$ \\
5 & $2_{\mathrm{e}}$ & $12.5 \mu \mathrm{g}$ & $25 \mu \mathrm{g}$ & $50 \mu \mathrm{g}$ & $25 \mu \mathrm{g}$ \\
6 & $2_{\mathrm{f}}$ & $25 \mu \mathrm{g}$ & $50 \mu \mathrm{g}$ & $25 \mu \mathrm{g}$ & $50 \mu \mathrm{g}$ \\
\hline
\end{tabular}

\section{CONCLUSION}

In continuation of our research program on 2aminothiophene, the present study focused on synthesizing 2-aminothiophene derivatives possessing different heterocyclic rings. The present study has given deep insight as the 2-aminothiophene bearing 4hydroxy benzaldehyde shown significant anti-microbial activity. In the light of results of this study the further research will be carried out considering each heterocyclic ring individually with the 2aminothiophene ring.

\section{ACKNOWLEDGEMENT}

The author is thankful to Swamiramanandatirtha Institute of Pharmaceutical Sciences, Nalgonda.

\section{REFERENCES}

1. Bhaskar VH et al. synthesis of some 4-substituted-5,6,7,8tetrahydro benzothieno[2,3-d] pyrimidines as Antimicrobial, hyperlipidemic agents," Asian J Chem., 19(7), 2007, 5187-5194.

2. Barnali $D$ et al. synthesis of some novel sulfur containing heterocyclic compounds,as Antifungal agents," Asian J Chem.19(5),2007,4118-4120.

3. Saravanan J et al. Synthesis of some 2-amino-3-(N-tolyl carboxamido)-4,5-pentamethylene thiophenes As
Potential antibacterial agents," Asian J Chem., 15(2), 2003, 625-628.

4. Santagati $M$ et al. Synthesis of Aminothieno pyrimidine and Thienotriazolo pyrimidine Derivatives as Potential Anticonvulsant Agents. Die Pharmazie, 51(1), 1996, 7-11.

5. Prasad M.R et al. Synthesis and Adenosine Receptor Binding Studies of Some Novel Triazolothieno pyrimidines. European Journal of Medicinal Chemistry, 43(3), 2008, 614-620.

6. A. E. Amr A.E et al. Synthesis and Antiinflammatory Activities of New Cyanopyrane Derivatives Fused with Steroidal Nuclei. Archiv der Pharmazie Chemistry Life Science, 339(2), 2006, 88-95.

7. Meenakshi $\mathrm{K}$ et al. Synthesis, characterization and antiinflammatory activity of 7-azaisatin derivatives, International journal of pharmacy and pharmaceutical analysis, 1(2), 2015, 2394-1618.

8. Jennings L. D et al. Parallel Synthesis and Biological Evaluation of 5, 6, 7, 8-Tetrahydrobenzothieno [2, 3- d] pyrimidin-4(3H)-one Cytotoxic Agents Selective for p21Deficient Cells," Bioorganic \& Medicinal Chemistry Letter, 15(21), 2005, 4731-4735.

9. El-Gazzar A. B. A et al. Synthesis and Biological Evaluation of Thieno[2, 3d]pyrimidine Derivatives as Antiinflammatory, Analgesic and Ulcerogenic Activity. Acta Pharmaceutica, 57(4), 2007, 395-411.

10. Zita Puterová et al. Gewald reaction: synthesis, properties and applications of substituted 2aminothiophenes, ARKIVOC, 2010 (i), 209-246. 